\title{
Protective Effect of Panduratin A on Cisplatin-Induced Apoptosis of Human Renal Proximal Tubular Cells and Acute Kidney Injury in Mice
}

\author{
Penjai Thongnuanjan, ${ }^{a, b}$ Sirima Soodvilai, ${ }^{c}$ Somsak Fongsupa, ${ }^{d}$ Napason Chabang, ${ }^{e}$ \\ Pornpun Vivithanaporn, ${ }^{f}$ Patoomratana Tuchinda, ${ }^{g}$ and Sunhapas Soodvilai*, ${ }^{*, b, g}$ \\ ${ }^{a}$ Toxicology Graduate Program, Multidisciplinary Unit, Faculty of Science, Mahidol University; Ratchathewi, \\ Bangkok 10400, Thailand: ${ }^{b}$ Research Center of Transport Protein for Medical Innovation, Department of Physiology, \\ Mahidol University; Ratchathewi, Bangkok 10400, Thailand: ${ }^{c}$ Department of Pharmaceutical Technology, College of \\ Pharmacy, Rangsit University; Pathumthani 12000, Thailand: ${ }^{d}$ Department of Medical Technology, Faculty of Allied

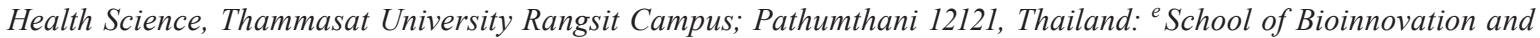 \\ Bio-based Product Intelligence, Faculty of Science, Mahidol University; Ratchathewi, Bangkok 10400, Thailand: \\ ${ }^{f}$ Chakri Naruebodindra Medical Institute, Faculty of Medicine Ramathibodi Hospital, Mahidol University; Samut \\ Prakan 10540, Thailand: and ${ }^{g}$ Excellent Center for Drug Discovery, Mahidol University; Ratchathewi, Bangkok \\ 10400, Thailand.
}

Received January 12, 2021; accepted March 25, 2021

Background: Cisplatin is an effective chemotherapy but its main side effect, acute kidney injury, limits its use. Panduratin A, a bioactive compound extracted from Boesenbergia rotunda, shows several biological activities such as anti-oxidative effects. The present study investigated the nephroprotective effect of panduratin $A$ on cisplatin-induced renal injury. Methods: We investigated the effect of panduratin $A$ on the toxicity of cisplatin in both mice and human renal cell cultures using RPTEC/TERT1 cells. Results: The results demonstrated that panduratin $A$ ameliorates cisplatin-induced renal toxicity in both mice and RPTEC/ TERT1 cells by reducing apoptosis. Mice treated with a single intraperitoneal (i.p.) injection of cisplatin $(20 \mathrm{mg} / \mathrm{kg}$ body weight (BW)) exhibited renal tubule injury and impaired kidney function as shown by histological examination and increased serum creatinine. Co-administration of panduratin A (50 mg/kg BW) orally improved kidney function and ameliorated renal tubule injury of cisplatin by inhibiting activation of extracellular signal-regulated kinase (ERK)1/2 and caspase 3. In human renal proximal tubular cells, cisplatin induced cell apoptosis by activating pro-apoptotic proteins (ERK1/2 and caspase 3), and reducing the anti-apoptotic protein (Bcl-2). These effects were significantly ameliorated by co-treatment with panduratin A. Interestingly, panduratin A did not alter intracellular accumulation of cisplatin. It did not alter the anticancer efficacy of cisplatin in either human colon or non-small cell lung cancer cell lines. Conclusions: The present study highlights panduratin A has a potential protective effect on cisplatin's nephrotoxicity.

Key words chemotherapy; acute kidney injury; panduratin A; human renal proximal tubule; anti-apoptosis

\section{INTRODUCTION}

Nephrotoxicity induced by drugs is a major problem in the clinical setting because the use of nephrotoxic drugs is often unavoidable. Nephrotoxicity can be defined by renal injuries including glomerular damage and tubular injury leading to impairment of renal function. ${ }^{1)}$ Common drugs associated with the kidney injury are anti-inflammatories, antibiotics, and chemotherapeutic agents, such as cisplatin. ${ }^{2-4)}$ Cisplatin is a broad-spectrum, high potency chemotherapeutic drug. ${ }^{5)}$ However, approximately one out of three patients receiving cisplatin treatment suffers from nephrotoxicity ${ }^{6,7)}$ and electrolyte imbalance. ${ }^{89}$ ) Cisplatin-induced nephrotoxicity is characterized by proximal tubule injury, vascular injury and inflammation. ${ }^{4}$ Accumulation of cisplatin in renal cells induces multiple pathways that promote cell death. Reactive oxygen species (ROS) has been identified as a key mediator in cisplatin nephrotoxicity. ${ }^{10,11)}$ Additionally, ROS induces nephrotoxicity via activation of mitogen-activated protein kinases (MAPKs). ${ }^{10,12,13)}$ Several studies have reported that cisplatin itself can directly stimulate extracellular signal-regulated kinase (ERK)1/2 (a member of MAPKs) both in vitro and in vivo. ${ }^{14,15}$ )

Certain phytochemicals ameliorate cisplatin-induced neph- rotoxicity by inhibiting ROS accumulation and apoptosis. ${ }^{16-18)}$ Although nephroprotective effects of these phytochemicals have been reported in preclinical studies, there is still no approved drugs from phytochemicals for cisplatin's nephrotoxicity (see detail in review) ${ }^{19)}$ Current clinical practice only provides supportive treatments to recover renal function. ${ }^{20}$ Therefore, it is still important to search for effective agents to prevent or treat cisplatin-induced nephrotoxicity. Panduratin A is an interesting phytochemical. It is a cyclohexanyl chalcone isolated from Boesenbergia rotunda, a plant used in traditional medicine and food. ${ }^{21)}$ Panduratin A has been shown to prevent or treat oxidative stress, inflammation and metabolic disease. $^{22,23)}$

Injury of renal proximal tubules caused by cisplatin is mediated, at least in part, via increased oxidative stress and inflammation. ${ }^{11)}$ Therefore, we investigated the effect of panduratin $\mathrm{A}$ on the toxicity of cisplatin in both animals and cell cultures using RPTEC/TERT1 cells. We also tested whether co-treatment with panduratin A affects cisplatin's anti-cancer activity in human cancer cell lines. 


\section{METERIALS AND METHODS}

Chemicals Thiazolyl blue tetrazolium bromide (MTT), $2^{\prime}, 7^{\prime}$-dichlorofluorescin diacetate (DCFH-DA), cisplatin and compound C (AMP-activated protein kinase (AMPK) inhibitor) were purchased from Sigma-Aldrich (MO, U.S.A.). ${ }^{3} \mathrm{H}-1$-Methyl-4-phenylpyridinium $\left({ }^{3} \mathrm{H}-\mathrm{MPP}^{+}\right)$was purchased from PerkinElmer, Inc. (Bangkok, Thailand). Annexin Vfluorescein isothiocyanate (FITC) apoptosis detection kit was purchased from BD Biosciences (CA, U.S.A.). Primary antibodies for p-ERK1/2 (Cat. No. 9102S), ERK1/2 (Cat. No, 9101S), Bcl-2 (Cat. No. 2872T), caspase-3 (Cat. No. 9662S), glyceraldehyde-3-phosphate dehydrogenase (GAPDH) (Cat. No. 2118S), p-AMPK $\alpha$ (Cat. No.2531S), AMPK $\alpha$ (Cat. No. 5832S), Bax (Cat. No. 5023) and $\beta$-actin (Cat. No. 4970T) antibodies were obtained from Cell Signaling (MA, U.S.A.) and anti-neutrophil gelatinase-associated lipocalin (NGAL) antibody (Cat. No. STCSC-515876) was purchased from Santa Cruz Biotechnology (CA, U.S.A.). Panduratin A $>98 \%$ purity determined by HPLC was isolated from Boesenbergia rotunda as previously described by our group. ${ }^{24)}$ The rhizomes of Boesenbergia rotunda were collected from Kanchanaburi, Thailand. The plant was identified by Tuanta Sematong. The voucher specimen (No. BKF 68909) has been deposited at the Forest Herbarium, Royal Forestry Department, Bangkok.

Animals Male C57BL/6 mice (8-weeks old) were purchased from Nomura Siam International Co., Ltd. (Bangkok, Thailand). Animal Care and Use Protocol No. MUSC61-063-464 has been approved by the Institutional Animal Care and Use Committee, MUSC-IACUC. The mice were allowed to freely access food and water. After one week of acclimatization, mice were divided randomly and administered treatments as follows: normal saline by a single intraperitoneal (i.p.) injection on day 4 (control group); panduratin $\mathrm{A}(50 \mathrm{mg} / \mathrm{kg}$ body weight $(\mathrm{BW}))$ by oral gavage for $7 \mathrm{~d}$ (panduratin A group); cisplatin ( $20 \mathrm{mg} / \mathrm{kg} \mathrm{BW})$ by a single i.p. injection on day 4 (cisplatin group); panduratin A $(50 \mathrm{mg} / \mathrm{kg}$ BW/d) by oral gavage for $7 \mathrm{~d}$ and cisplatin $(20 \mathrm{mg} / \mathrm{kg} \mathrm{BW})$ by a single i.p. injection on day 4 (co-treatment group). On day 7 , mice were deeply anaesthetized by thiopental sodium. Blood was drawn and centrifuged for $10 \mathrm{~min}$ at $3000 \mathrm{rpm}$. The collected supernatants were kept at $-80^{\circ} \mathrm{C}$ until renal function was measured. Kidneys were collected for measurement of protein expressions and histopathological studies.

Determination of Renal Function and Histological Examination Renal function was determined by measuring serum creatinine using Stanbio Creatinine Liquicolor (NY, U.S.A.) and blood chemistry analyzer, Licenza (Rome, Italy). To examine cisplatin-induced renal tubular damage, mouse kidneys were fixed in $4 \%$ paraformaldehyde. The kidney slices were stained with hematoxylin and eosin (H\&E) photographed by a light microscope. The percentage of tubular injury was used to evaluate the renal tubular injury: $0=$ no tubular injury $1=<10 \% ; 2=10-25 \% ; 3=26-50 \% ; 4=51-75 \%$; $5=>75 \%$. Slides were blind scored by a pathologist. The mean score for each group of animals was calculated by counting 10 different fields of a slide.

Cell Lines RPTEC/TERT1 cells, colon cancer cells (HCT116) and non-small cell lung cancer cells (A549) were purchased from American Type Culture Collection (VA, U.S.A.). Briefly, RPTEC/TERT1 cells were cultured in com- plete Dulbecco's modified Eagle's medium/F-12 medium (DMEM/F12) as previously described. ${ }^{25)}$ HCT116 and A549 cells were cultured in DMEM/F12 and RPMI1640 medium, respectively, supplemented with penicillin-streptomycin antibiotics and $10 \%$ fetal bovine serum (FBS). Cells were cultured at $37^{\circ} \mathrm{C}$ in a humidified atmosphere of $5 \% \mathrm{CO}_{2}$ and $95 \% \mathrm{O}_{2}$.

Cell Viability Assay and Cell Apoptosis Analysis Cell viability was determined by exposing the RPTEC/TERT1 cells to $0.5 \mathrm{mg} / \mathrm{mL}$ MTT reagent for $1 \mathrm{~h}$ at $37^{\circ} \mathrm{C}$. The reagents were removed, the formazan salt formed was dissolved in dimethyl sulfoxide (DMSO) and detected by EnVision microplate reader at $570 \mathrm{~nm}$ absorbance. Cell viability was reported as a percentage of control. Annexin $\mathrm{V}$ and propidium iodide (PI) staining analysis was used to determine cell apoptosis. Briefly, RPTEC/TERT1 cells were detached by $0.25 \%$ trypsinethylenediaminetetraacetic acid (EDTA). The cell suspensions were incubated with Annexin V-FITC and PI in the dark at $4^{\circ} \mathrm{C}$ for $15 \mathrm{~min}$ followed by twice washing with binding buffer. Apoptotic cells were counted by flow cytometer and expressed as a percent of total cells.

Assessment of Intracellular ROS Accumulation ROS levels were determined by DCFH-DA assay. RPTEC/TERT1 cells were incubated with $10 \mu \mathrm{M}$ DCFH-DA and incubated for $30 \mathrm{~min}$ at $37^{\circ} \mathrm{C}$. Next, DCFH-DA dye was removed and cells were washed with phosphate buffered saline (PBS). Intracellular ROS level was measured at wavelengths of 485 and $530 \mathrm{~nm}$ for excitation and emission, respectively. Intracellular ROS accumulation is reported as a percentage of fluorescent intensity relative to control cells.

Platinum Accumulation Analysis Accumulated platinum was measured in both digested RPTEC/TERT1 cells and mouse kidneys by UNICAM 989 QZ AA spectrometer (Geleen, Netherlands). Ten microliter of $1 \%$ triton X-100 and $400 \mu \mathrm{L}$ of $1 \%$ nitric acid were added to each $100 \mu \mathrm{L}$ sample. Samples were then incubated for at least $1 \mathrm{~h}$. Prior to platinum detection, each sample was diluted 10:1 with $1 \%$ nitric acid. The platinum concentration was calculated using linear regression of a platinum standard curve prepared using $2.5 \mathrm{mg} / \mathrm{mL}$ of cisplatin-diluted in $1 \%$ nitric acid. The platinum was calculated as ng/cell number or ng/kidney weight.

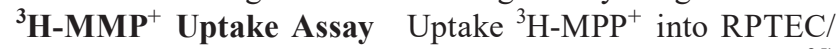
TERT1 cells was determined using our previous method. ${ }^{25)}$ Briefly, cells were washed with warm transport buffer and further incubated for $20 \mathrm{~min}$. The cell monolayers were incubated with ${ }^{3} \mathrm{H}-\mathrm{MPP}^{+}(10 \mathrm{nM})$ followed by washing with ice-cold transport buffer. The samples were collected and radioactive activity of ${ }^{3} \mathrm{H}-\mathrm{MPP}^{+}$was measured using liquid scintillation counter.

Western Blotting Analysis Protein expressions were processed according to our previous study. ${ }^{26)}$ Extracted proteins from mouse kidney and RPTEC/TERT1 cells were centrifuged at $12000 \mathrm{rpm}$ for $20 \mathrm{~min}$ at $4{ }^{\circ} \mathrm{C}$. Equal amounts of proteins isolated from cells and tissue were denatured and separated by $10-12 \%$ sodium dodecyl sulfate-polyacrylamide gel electrophoresis (SDS-PAGE). Samples were transferred onto nitrocellulose membranes followed by $1 \mathrm{~h}$ non-specific protein blocking using nonfat dry milk $(5 \%)$. The membranes were incubated with primary antibody for $24 \mathrm{~h}$ and were then incubated with secondary antibody for $1 \mathrm{~h}$. The intensity of protein expression was detected using chemiluminescent HRP substrate and quantified by ImageJ software. 
A

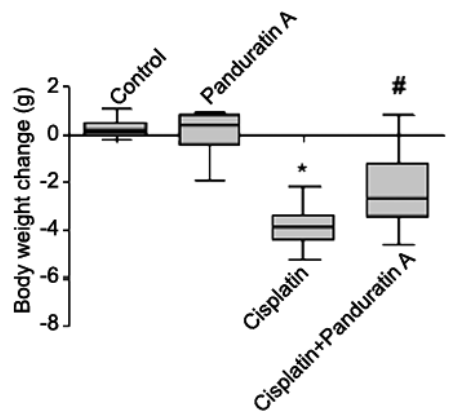

B

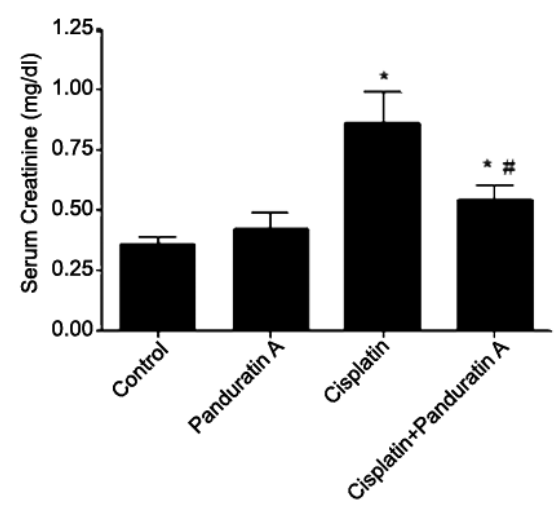

C

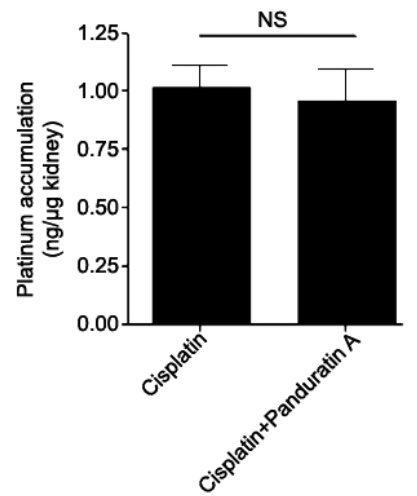

Fig. 1. The Effect of Panduratin A on Kidney Injury Caused by Cisplatin

C57BL/6 mice were treated with saline solution, panduratin A $(50 \mathrm{mg} / \mathrm{kg} \mathrm{BW})$ orally for $7 \mathrm{~d}$, cisplatin $(20 \mathrm{mg} / \mathrm{kg} \mathrm{BW})$ i.p. injection on day 4 , panduratin A (50 mg/kg BW) for $7 \mathrm{~d}$ and cisplatin $(20 \mathrm{mg} / \mathrm{kg} \mathrm{BW})$ on day 4 . (A) Body weight change, (B) serum creatinine, (C) Platinum accumulation in renal tissue. Data are shown as mean \pm S.D from 6 animals; ${ }^{*} p<0.01 v s$. control group and ${ }^{\#} p<0.01 v s$. cisplatin group.
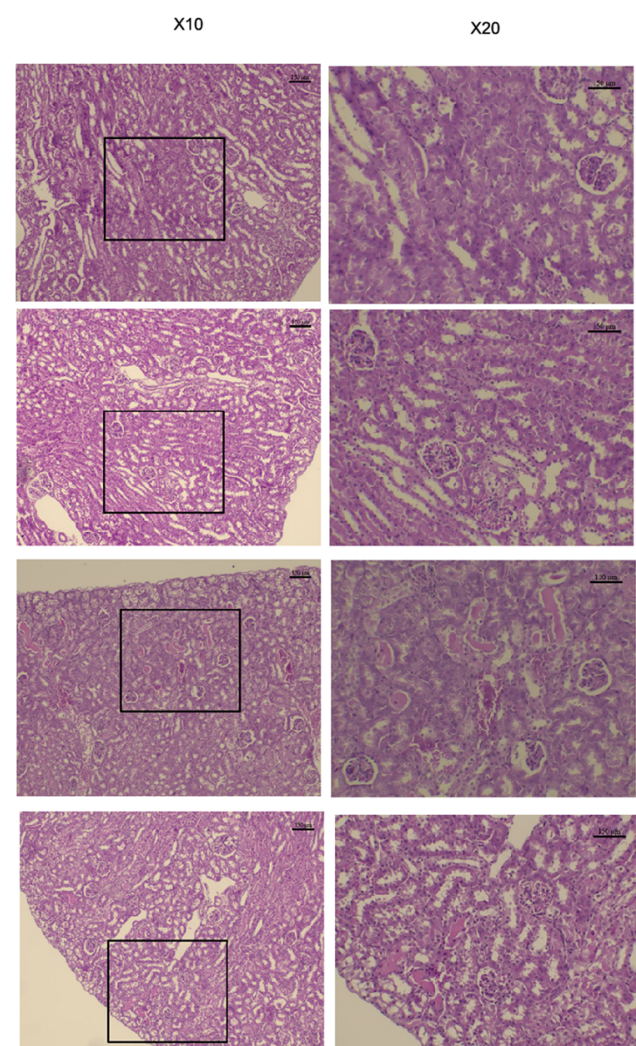
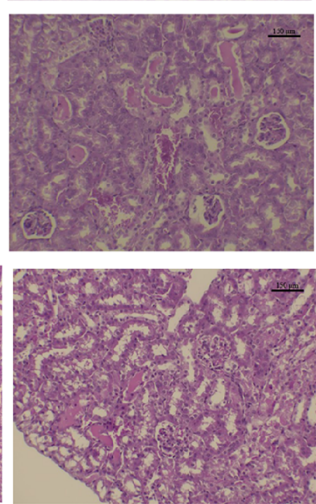

B

Control
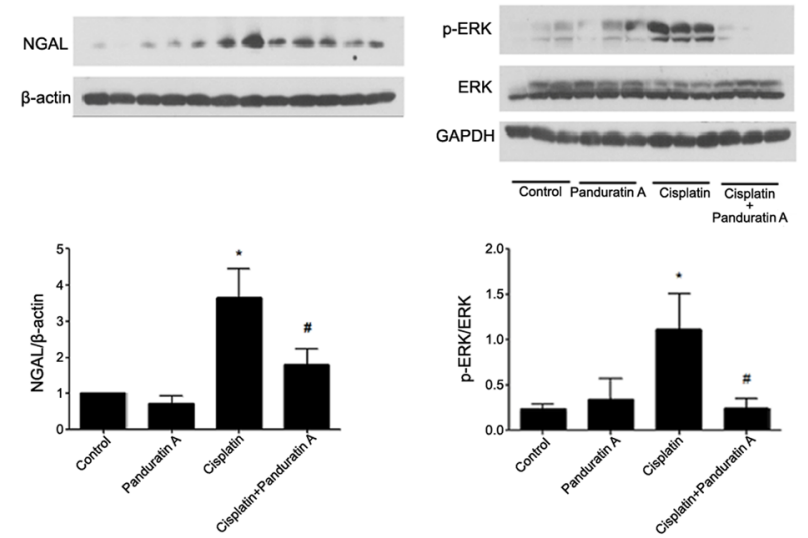

\section{Cisplatin
$(20 \mathrm{mg} / \mathrm{kg})$}
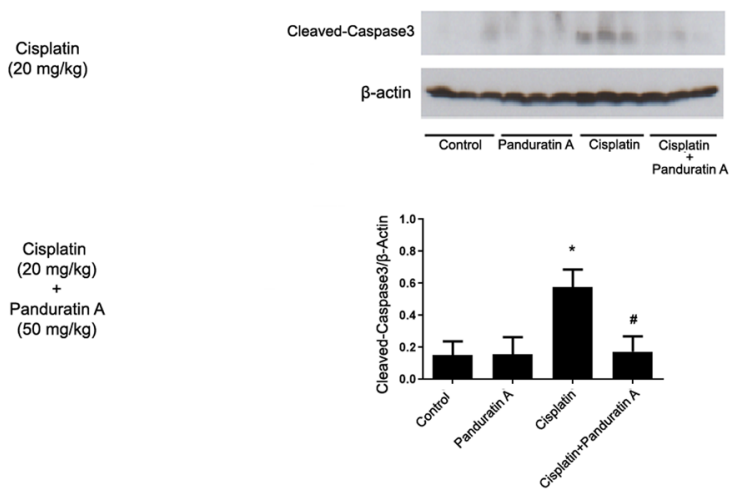

Fig. 2. Effect of Panduratin A on Cisplatin-Induced Renal Toxicity

(A) Photomicrographs of H\&E-stained renal tissue and (B) expression of NGAL, ERK, and cleaved caspase 3. Data are from 6 animals and expressed as mean \pm S.D.; ${ }^{*} p<0.01 v s$. control group and ${ }^{\#} p<0.01 v s$. cisplatin group. (Color figure can be accessed in the online version.)

Statistical Analysis Data are expressed as mean \pm standard deviation (S.D.). Data were analyzed by one-way ANOVA using Tukey's post-hoc tests (GraphPad Prism 8.0). A significance is considered when $p$ value is less than 0.05 .

\section{RESULTS}

Panduratin A Ameliorates Cisplatin-Induced Acute Kidney Injury We investigated the effect of panduratin A on kidney injury caused by cisplatin in mice. We first observed the general toxicity by measuring body weight change in mice following treatment with normal saline, panduratin A 
$(50 \mathrm{mg} / \mathrm{kg} \mathrm{BW})$, cisplatin $(20 \mathrm{mg} / \mathrm{kg} \mathrm{BW})$, and both cisplatin $(20 \mathrm{mg} / \mathrm{kg} \mathrm{BW})$ and panduratin A $(50 \mathrm{mg} / \mathrm{kg} \mathrm{BW})$. A significant decreased body weight in the cisplatin-treated mice was found. The body weight loss was mitigated by co-treatment with panduratin A (Fig. 1A). Compared with the control, kidney function which was measured by serum creatinine level showed that mice-treated panduratin A alone did not alter serum creatinine level; whereas the cisplatin-treated mice had significantly increased serum creatinine levels, indicating impaired kidney function. The serum creatinine level in co-administration of panduratin A was significantly decreased compared with cisplatin-treated mice (Fig. 1B). In addition, the accumulation of platinum in kidney tissue was not significantly different in mice treated with cisplatin alone compared with mice co-treated with cisplatin and panduratin A (Fig. 1C). These data indicate that panduratin A did not affect cisplatin content in renal tissue. The kidneys obtained from mice treated with vehicle or panduratin A alone showed no marked pathological changes. However, cisplatin-treated mice showed more tubular damage compared with vehicle-treated mice as shown by increase in degeneration and desquamation, formation of luminal casts, mononuclear cell infiltration, karyomegaly, inter-tubular haemorrhagia, and dilation. These pathological changes were significantly attenuated by co-administration of panduratin A (Fig. 2A, Table 1). The expression levels of NGAL (a nephrotoxicity biomarker), and ERK1/2 and cleaved caspase 3 (pro-apoptotic proteins) were determined. Our study showed that mice treated with cisplatin significantly increased expression of NGAL, p-ERK1/2, and cleaved caspase 3 compared with vehicle-treated mice. Co-treatment with panduratin A significantly reduced these proteins induced by cisplatin treatment (Fig. 2B).

Panduratin A Prevents Cisplatin-Induced Cytotoxicity in Human Renal Proximal Tubular Cells by Inhibiting Apoptotic Signaling Pathways Cisplatin $(50 \mu \mathrm{M})$ significantly decreased viability of RPTEC/TERT1 cells following $72 \mathrm{~h}$ incubation. Interestingly, co-treatment with panduratin A $(1$ and $5 \mu \mathrm{M})$ significantly increased cell viability (Fig.

Table 1. Effect of Panduratin A on Cisplatin-Induced Renal Tubular Damage

\begin{tabular}{|c|c|c|c|c|c|c|c|}
\hline Group & Tubular necrosis & $\begin{array}{l}\text { Tubular degenera- } \\
\text { tion \& desquamation }\end{array}$ & $\begin{array}{l}\text { Luminal casts } \\
\text { formation }\end{array}$ & Karyomegaly & $\begin{array}{l}\text { Mononuclear cell } \\
\text { infiltration }\end{array}$ & $\begin{array}{l}\text { Inter-tubular } \\
\text { haemorrhagia }\end{array}$ & Tubular dilation \\
\hline Control & $0.00 \pm 0.00$ & $0.00 \pm 0.00$ & $0.00 \pm 0.00$ & $0.00 \pm 0.00$ & $0.25 \pm 0.43$ & $0.00 \pm 0.00$ & $0.50 \pm 0.50$ \\
\hline Panduratin A & $0.20 \pm 0.40$ & $0.80 \pm 0.40$ & $0.00 \pm 0.00$ & $0.00 \pm 0.00$ & $0.20 \pm 0.40$ & $0.40 \pm 0.49$ & $0.60 \pm 0.49$ \\
\hline Cisplatin & $0.40 \pm 0.49$ & $1.40 \pm 0.49 *$ & $2.00 \pm 0.89 *$ & $1.20 \pm 0.40 *$ & $1.40 \pm 0.49 *$ & $1.40 \pm 0.49 *$ & $1.80 \pm 0.75^{*}$ \\
\hline Cisplatin + Panduratin A & $0.20 \pm 0.40$ & $0.20 \pm 0.40^{\#}$ & $0.20 \pm 0.40^{\#}$ & $0.00 \pm 0.00^{\#}$ & $0.00 \pm 0.00^{\#}$ & $0.00 \pm 0.00^{\#}$ & $1.00 \pm 0.63^{\#}$ \\
\hline
\end{tabular}

Data are shown as mean \pm S.D. from 5 animals; ${ }^{*} p<0.01 v$ s. control group and ${ }^{\#} p<0.01 v s$. cisplatin group.

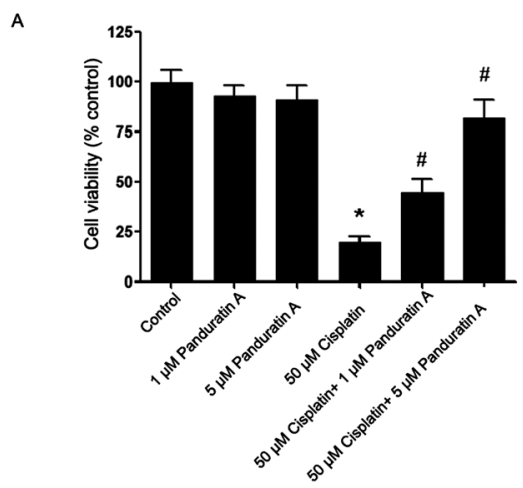

c

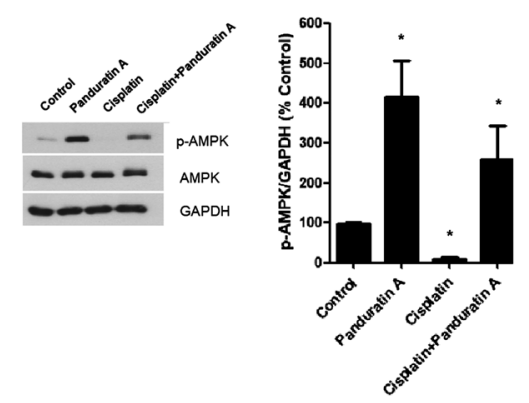

B
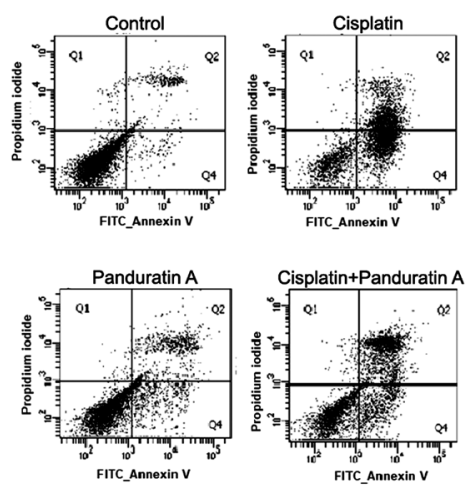

D

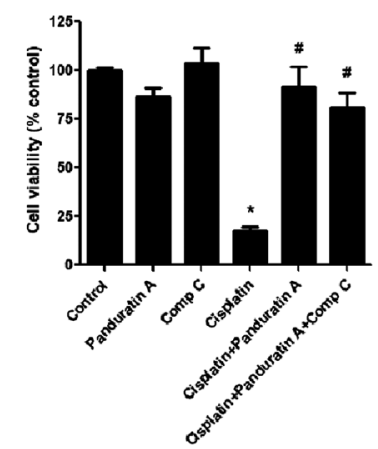

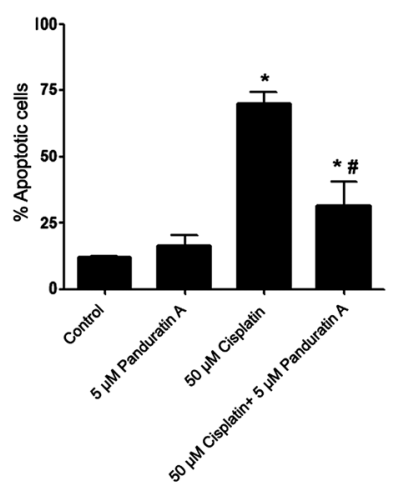

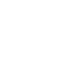

Fig. 3. Effect of Panduratin A in Renal Proximal Tubular Cells

(A) Cell viability measurement following for $72 \mathrm{~h}$. treatment; (B) p-AMPK expression was measured after $24 \mathrm{~h}$. treatment with vehicle, panduratin A (5 $\mu$ M), cisplatin $(50 \mu \mathrm{M})$, and cisplatin combined with panduratin $\mathrm{A} ;(\mathrm{C})$ Cell viability measurement following for $72 \mathrm{~h}$. Treatment with vehicle, panduratin $\mathrm{A}(5 \mu \mathrm{M})$, cisplatin $(50 \mu \mathrm{M})$, and cisplatin combined with panduratin A; (D) Cell apoptosis was measured after $48 \mathrm{~h}$ treatment. Data are reported as mean \pm S.D. of $\%$ control $(n=3) ; * p<0.05 v s$. control group and ${ }^{\#} p<0.05$ vs. cisplatin group. 
3A). Panduratin A's protective effect against cytotoxicity of cisplatin was confirmed by measurement of cell apoptosis. As expected, exposure of the cells to $50 \mu \mathrm{M}$ cisplatin for $48 \mathrm{~h}$ significantly increased apoptosis of RPTEC/TERT1 cells. This effect was attenuated by panduratin A (Fig. 3B). We examined whether the effect of panduratin A on cisplatin's toxicity required activation of AMPK. As shown in Fig. 3C, protein expression of $\mathrm{p}$-AMPK, an active form of AMPK, was increased by panduratin A whereas it was decreased by cisplatin. In addition, the protective effect of panduratin A under AMPK inhibition was determined. Interestingly, incubation of the cells with $10 \mu \mathrm{M}$ compound $\mathrm{C}$, an inhibitor of AMPK, did not attenuate the protective effect of panduratin $\mathrm{A}$ on cell viability (Fig. 3D). These results indicate that the protective effect of panduratin A might be mediated by AMPK-independent mechanisms. We next examined the effect of panduratin A on certain proteins involved in cell apoptosis induced by cisplatin. As shown in Fig. 4, cisplatin significantly increased pro-apoptotic proteins $\mathrm{p}-\mathrm{ERK} 1 / 2$ and cleaved caspase 3 . Cisplatin decreased expression of anti-apoptotic protein Bcl-2. Co-treatment with panduratin A reversed the expression of these proteins. Since ROS is a major factor involved in renal cell apoptosis induced by cisplatin, ${ }^{11,27)}$ we determined the effect of panduratin A on ROS accumulation due to cisplatin. Cisplatin significantly increased intracellular levels of ROS. Interestingly, panduratin A significantly reduced cisplatininduced ROS accumulation.

Panduratin A Does Not Affect Cellular Accumulation of Cisplatin OCT2 mediates cisplatin transport into the human renal proximal tubular cells. ${ }^{28,29)}$ To examine the possibility of panduratin A reducing cisplatin accumulation, we measured the transport function of OCT2. The results showed that incubation of cells with $5 \mu \mathrm{M}$ panduratin A for $10 \mathrm{~min}$ and $24 \mathrm{~h}$ had no effect on cellular accumulation of ${ }^{3} \mathrm{H}-1-$ methyl-4-phenylpyridinium $\left({ }^{3} \mathrm{H}-\mathrm{MPP}^{+}\right)$, a substrate of OCT2. Next, the effect of panduratin $\mathrm{A}$ on cisplatin cellular accumulation was confirmed. Panduratin A had no significant effect on platinum accumulation in the human renal cells (Fig. 5).

The Protective Effect of Panduratin A Does Not Affect the Anti-cancer Activity of Cisplatin Panduratin A's effect on cisplatin's toxicity in cancer cell lines was determined. Viability of HCT116 and A549 cells which are colon and lung cancer cell lines, respectively, was significantly reduced $72 \mathrm{~h}$ after treatment with cisplatin $(50 \mu \mathrm{M})$. Co-treatment with panduratin $\mathrm{A}(5 \mu \mathrm{M})$ did not attenuate the cytotoxicity of cisplatin. Interestingly, panduratin A by itself also reduced the
A

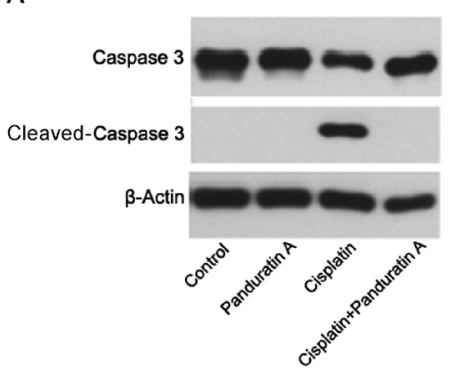

B

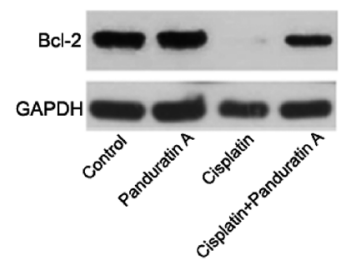

C

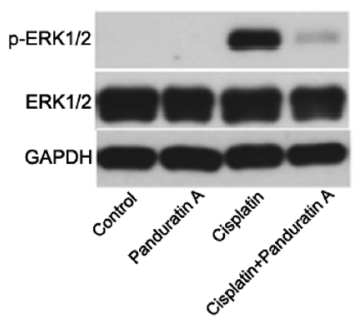

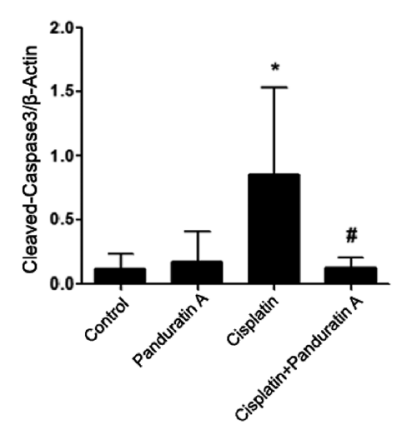

D

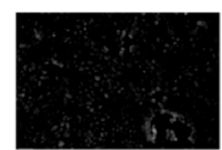

Control

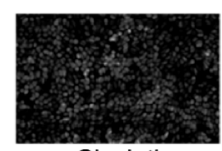

Cisplatin

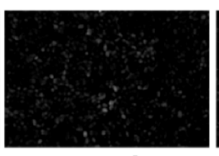

NAC

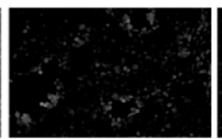

Cisplatin +NAC

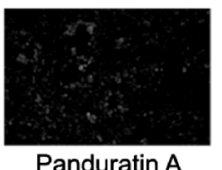

Panduratin A
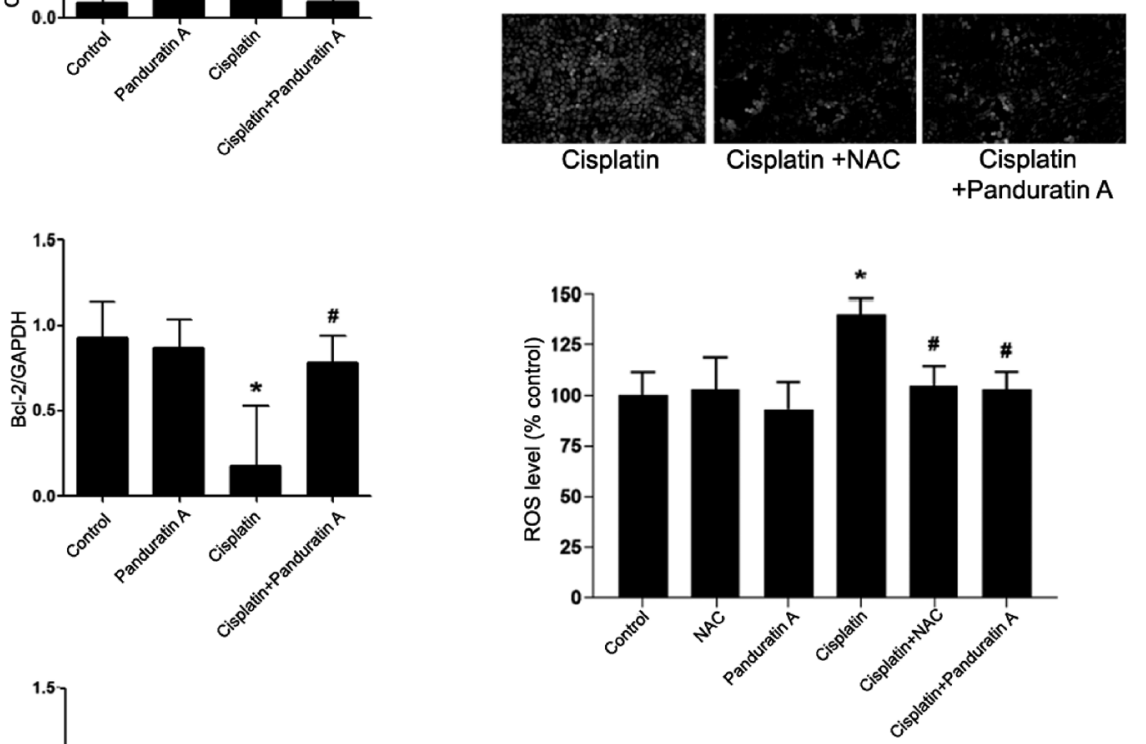

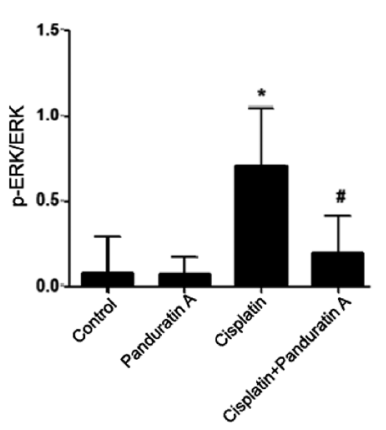

Fig. 4. Effect of Panduratin A on Expression of Signaling Proteins Involved in Apoptosis (A-C) and ROS Accumulation Due to Cisplatin (D)

Cells were incubated for $24 \mathrm{~h}$ with vehicle, panduratin A $(5 \mu \mathrm{M}), N$-acetylcysteine (NAC; $1 \mathrm{mM})$, cisplatin $(50 \mu \mathrm{M})$, and cisplatin $(50 \mu \mathrm{M})$ combined with panduratin A $(5 \mu \mathrm{M})$ or NAC $(1 \mathrm{mM})$. Data are reported as means \pm S.D. $(n=3) ;{ }^{*} p<0.05$ compared with vehicle-treated cells and ${ }^{\#} p<0.05$ compared with cisplatin-treated cells. 
A

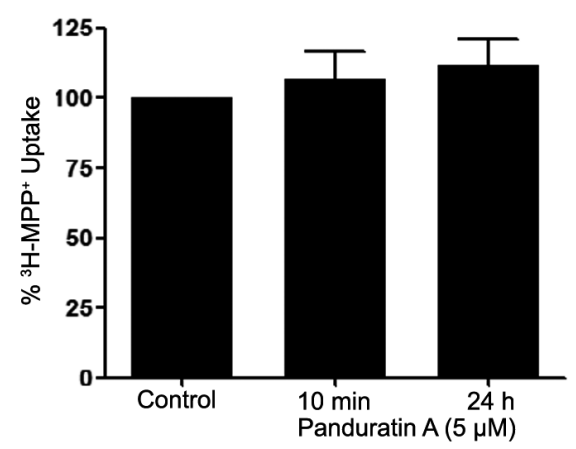

B

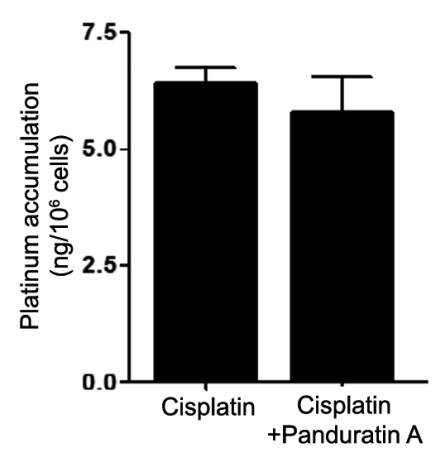

Fig. 5. Effect of Panduratin A on ${ }^{3} \mathrm{H}-\mathrm{MPP}^{+}$and Cisplatin Accumulation in RPTEC/TERT1 Cells

(A) Cells were incubated for $10 \mathrm{~min}$ or $24 \mathrm{~h}$ with vehicle or panduratin A $(5 \mu \mathrm{M})$ followed by measurement of ${ }^{3} \mathrm{H}-\mathrm{MPP}{ }^{+}$cellular accumulation. (B) Cells were incubated for $3 \mathrm{~h}$ with cisplatin $(100 \mu \mathrm{M})$ alone or co-treated with panduratin $\mathrm{A}(5 \mu \mathrm{M})$, then cellular platinum accumulation was determined. Data are shown as mean \pm S.D. $(n=4)$.
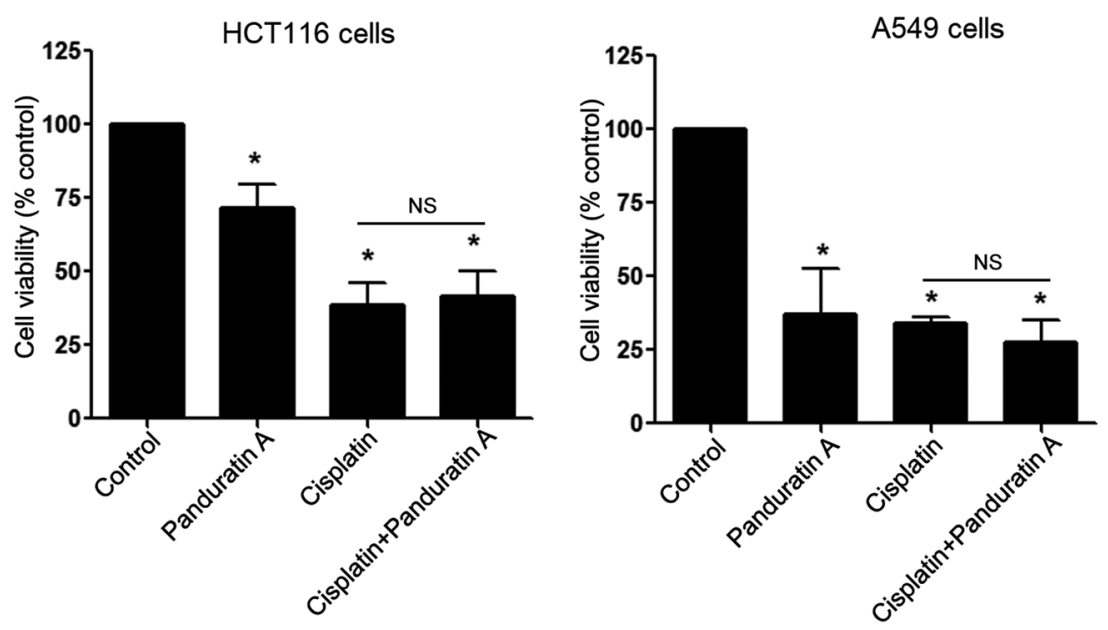

Fig. 6. Effect of Panduratin A on Anti-cancer Activity of Cisplatin

HCT116 cells and A549 cells were incubated for $72 \mathrm{~h}$ with vehicle, panduratin A $(5 \mu \mathrm{M})$, cisplatin $(50 \mu \mathrm{M})$, cisplatin $(50 \mu \mathrm{M})$ and panduratin A $(5 \mu \mathrm{M})$ followed by cell viability measurement. Data are reported as mean \pm S.D. $(n=3) ;{ }^{*} p<0.05 v$ s. control group and NS represents non-significance.

viability of these cells (Fig. 6).

\section{DISCUSSION}

The present study reveals that panduratin A reduces cisplatin nephrotoxicity without impairing cisplatin's anti-cancer activity in colon and non-small cell lung cancer cell lines. We showed that co-treatment with panduratin A attenuates acute kidney injury in mice caused by cisplatin. Although the present study shows the protective effect on cisplatin-induced kidney injury, the primary target of panduratin $\mathrm{A}$ is not identified. Panduratin A could activate AMPK in renal proximal tubular cells (Fig. 3) and other cell types. ${ }^{30-32)}$ It seems unlikely that the protective effect of panduratin $\mathrm{A}$ requires activation of AMPK as evidence showed that inhibition of AMPK using chemical inhibitor did not alter the protective effect of panduratin $\mathrm{A}$.

Panduratin A improved renal function as shown by reduced serum creatinine. Cisplatin-impaired renal function is correlated with renal tubule injury such as degeneration, luminal cast formation, haemorrhagia, and dilation. The renal tubule injury results correlated well with our data showing the induction of NGAL expression in kidney tissue of mice treated with cisplatin. In addition, this evidence is supported by the previous study showing NGAL is markedly expressed in renal tubules following acute kidney injury induced by cisplatin. ${ }^{33)}$ Interestingly, co-treatment of the mice with panduratin A attenuated cisplatin-induced renal tubule injury. The histological analysis showed that cisplatin increased mononuclear cell infiltration and this effect was abolished by panduratin A. These results imply that panduratin A, which is previously shown an antiinflammation, ${ }^{24,34,35)}$ might attenuate the inflammatory effect of cisplatin in renal tissue. MAPK activation could induce cell death. $^{12,14,15)}$ Our results showed that cisplatin stimulated activation of ERK1/2 and caspase 3. Expressions of these proteins were attenuated by panduratin A.

Multiple pathways contributing to cisplatin-induced nephrotoxicity (including apoptosis, oxidative stress, and inflammation) have been reported. ${ }^{4)}$ We used RPTEC/TERT1 cell line to identify mechanisms of panduratin A ameliorating toxicity caused by cisplatin in human renal proximal tubular cells. RPTEC/TERT1 cells have been suggested as a renal cell model for xenobiotic-induced toxicities. ${ }^{36)}$ Panduratin A exhibits a protective effect in respect of cisplatin cytotoxicity as shown by a decrease in RPTEC/TERT1 cell apoptosis. The mechanisms of cisplatin's toxicity in renal proximal tubular cells are complex. ERK1/2 and caspase 3 activation and Bcl-2 depletion have been implicated in renal cell apoptosis due to 
cisplatin. ${ }^{37,38)}$ Consistent with previous studies, the present study showed that cisplatin increases expression of $\mathrm{p}$-ERK1/2 and cleaved caspase 3 and decreases Bcl-2 expression. Our results indicate that panduratin A suppresses cisplatin-induced apoptotic signaling proteins, p-ERK1/2 and cleaved caspase 3 , and maintains anti-apoptotic protein, Bcl-2. In addition to activation of ERK1/2 and caspase 3, increased intracellular ROS accumulation is a key factor in renal cell apoptosis due to cisplatin. ${ }^{11,39)}$ A previous study reported that panduratin A protects against oxidative damage in hepatocytes by reducing intracellular ROS formation caused by reactive intermediates. ${ }^{40)}$ The decrease in ROS accumulation following treatment with panduratin A could be mediated by either inhibition of ROS production or increase in ROS scavenging reaction. We reported that panduratin A increased glutathione level, an ROS scavenging molecule, which might reduce ROS accumulation in renal tissue (see supplementary materials). However, we do not rule out other mechanisms are involved in ROS reduction. Our results revealed that panduratin A reduces intracellular ROS accumulation, which contributes to panduratin A's protective effect. Intracellular level of cisplatin is the primary factor affecting the severity of cisplatin-induced toxicity. Renal transporters such as OCT2, copper transporters and multidrug and toxin extrusion transporter-1 (MATE1) have been reported to contribute to cisplatin transport. ${ }^{41)}$ However, transport of cisplatin into the renal proximal tubular cells is primarily mediated by OCT2. Inhibition of OCTs has been shown to attenuate cisplatin-induced renal toxicity both in cultured renal cells and animals. ${ }^{28,29,42)}$ However, it seems likely that panduratin A does not affect OCT2 transport function or accumulation of cisplatin suggesting panduratin A's protective effect against cisplatin's toxicity is not mediated by reducing transport or accumulation of cisplatin.

Panduratin A exhibits renoprotective effects via the inhibition of renal cell apoptosis. If panduratin A also inhibited cancer cell apoptosis, it would reduce the chemotherapy efficacy. We therefore tested whether panduratin A reduces cisplatin's anti-cancer activity. Significantly, co-treatment with panduratin $\mathrm{A}$ does not alter the anti-cancer activity of cisplatin in either colon or non-small lung cell cancer cells. Moreover, panduratin A itself is toxic to both cancer cell lines. The results indicate that panduratin A's effect is selective, affecting normal renal cells and cancer cells differently. Although panduratin A might be a good agent for preventing of cisplatininduced nephrotoxicity, the information concerning the pharmacological effects of panduratin A under clinically relevant in xenograft model should be investigated in the future.

\section{CONCLUSION}

Our present study demonstrated that panduratin A provides a marked protective effect on cisplatin's nephrotoxicity by reducing oxidative stress and inhibiting ERK1/2 and caspase 3 activations. The protective effect of panduratin $\mathrm{A}$ did not alter the anti-cancer activity of cisplatin in cancer cells. Even though blocking some injurious events may only have partial renoprotective effects, panduratin A might be a good candidate agent to alleviate cisplatin's nephrotoxicity because it reduces toxicity of cisplatin via multiple mechanisms.

Acknowledgments This study was supported by the
International Research Network (IRN), Thailand Research Funds (Grant No. IRN5804PHDW02 to Penjai Thongnuanjan), Thailand Science Research and Innovation (Grant No. RSA6280082 to Sunhapas Soodvilai), and The Central Instrument Facility (CIF), Faculty of Science, Mahidol, University.

Author Contributions Pe. T. and Su. S. conceived the studies and planned the experimental design. Pe. T., Si. S., S. F., N. C., and Su. S. performed the experiments analyzed the data. Pe. T., Pa. T., and Su. S. interpreted the data. Pe. T. and Su. S. wrote manuscript. Su. S. edited and proved the final manuscript.

Conflict of Interest The authors declare no conflict of interest.

Supplementary Materials The online version of this article contains supplementary materials.

\section{REFERENCES}

1) Sánchez-González PD, Lopez-Hernandez FJ, Lopez-Novoa JM, Morales AI. An integrative view of the pathophysiological events leading to cisplatin nephrotoxicity. Crit. Rev. Toxicol., 41, 803-821 (2011).

2) Eras J, Perazella MA. NSAIDs and the kidney revisited: are selective cyclooxygenase-2 inhibitors safe? Am. J. Med. Sci., 321, 181-190 (2001).

3) Ozkan G, Ulusoy S, Orem A, Alkanat M, Mungan S, Yulug E, Yucesan FB. How does colistin-induced nephropathy develop and can it be treated? Antimicrob. Agents Chemother., 57, 3463-3469 (2013).

4) Pabla N, Dong Z. Cisplatin nephrotoxicity: mechanisms and renoprotective strategies. Kidney Int., 73, 994-1007 (2008).

5) Dasari S, Tchounwou PB. Cisplatin in cancer therapy: molecular mechanisms of action. Eur. J. Pharmacol., 740, 364-378 (2014).

6) Lebwohl D, Canetta R. Clinical development of platinum complexes in cancer therapy: an historical perspective and an update. Eur. J. Cancer, 34, 1522-1534 (1998).

7) Tsang RY, Al-Fayea T, Au HJ. Cisplatin overdose: toxicities and management. Drug Saf., 32, 1109-1122 (2009).

8) Aydinoz S, Uzun G, Cermik H, Atasoyu EM, Yildiz S, Karagoz B, Evrenkaya R. Effects of different doses of hyperbaric oxygen on cisplatin-induced nephrotoxicity. Ren. Fail., 29, 257-263 (2007).

9) Hatakeyama S, Shida T, Yamaguchi H. Risk factors for severe hyponatremia related to cisplatin: a retrospective case-control study. Biol. Pharm. Bull., 42, 1891-1897 (2019).

10) Ma ZN, Liu Z, Wang Z, Ren S, Tang S, Wang YP, Xiao SY, Chen $\mathrm{C}$, Li W. Supplementation of American ginseng berry extract mitigated cisplatin-evoked nephrotoxicity by suppressing ROS-mediated activation of MAPK and NF- $\kappa$ B signaling pathways. Food Chem. Toxicol., 110, 62-73 (2017).

11) Marullo R, Werner E, Degtyareva N, Moore B, Altavilla G, Ramalingam SS, Doetsch PW. Cisplatin induces a mitochondrial-ROS response that contributes to cytotoxicity depending on mitochondrial redox status and bioenergetic functions. PLOS ONE, 8, e81162 (2013)

12) Cassidy H, Radford R, Slyne J, O'Connell S, Slattery C, Ryan MP McMorrow T. The role of MAPK in drug-induced kidney injury. $J$. Signal Transduct., 2012, 463617 (2012).

13) Meng XM, Ren GL, Gao L, Yang Q, Li HD, Wu WF, Huang C, Zhang L, Lv XW, Li J. NADPH oxidase 4 promotes cisplatininduced acute kidney injury via ROS-mediated programmed cell death and inflammation. Lab. Invest., 98, 63-78 (2018).

14) Jo SK, Cho WY, Sung SA, Kim HK, Won NH. MEK inhibitor, 
U0126, attenuates cisplatin-induced renal injury by decreasing inflammation and apoptosis. Kidney Int., 67, 458-466 (2005).

15) Kim YK, Kim HJ, Kwon CH, Kim JH, Woo JS, Jung JS, Kim JM. Role of ERK activation in cisplatin-induced apoptosis in OK renal epithelial cells. J. Appl. Toxicol., 25, 374-382 (2005).

16) Okur ME, Ayla S, Karadag AE, Cicek Polat D, Demirci S, Seckin I. Opuntia ficus indica fruits ameliorate cisplatin-induced nephrotoxicity in mice. Biol. Pharm. Bull., 43, 831-838 (2020).

17) Soodvilai S, Meetam P, Siangjong L, Chokchaisiri R, Suksamrarn A, Soodvilai S. Germacrone reduces cisplatin-induced toxicity of renal proximal tubular cells via inhibition of organic cation transporter. Biol. Pharm. Bull., 43, 1693-1698 (2020).

18) Sultana S, Verma K, Khan R. Nephroprotective efficacy of chrysin against cisplatin-induced toxicity via attenuation of oxidative stress. J. Pharm. Pharmacol., 64, 872-881 (2012).

19) Ojha S, Venkataraman B, Kurdi A, Mahgoub E, Sadek B, Rajesh M. Plant-derived agents for counteracting cisplatin-induced nephrotoxicity. Oxid. Med. Cell. Longev., 2016, 4320374 (2016).

20) Ozkok A, Edelstein CL. Pathophysiology of cisplatin-induced acute kidney injury. Biomed Res. Int., 2014, 967826 (2014).

21) Eng-Chong T, Yean-Kee L, Chin-Fei C, Choon-Han H, Sher-Ming W, Li-Ping CT, Gen-Teck F, Khalid N, Abd Rahman N, Karsani SA, Othman S, Othman R, Yusof R. Boesenbergia rotunda: from ethnomedicine to drug discovery. Evid. Based Complement. Alternat. Med., 2012, 473637 (2012).

22) Chahyadi A, Hartati R, Wirasutisna KR, Elfahmi. Boesenbergia pandurata Roxb., an Indonesian medicinal plant: phytochemistry, biological activity, plant biotechnology. Procedia Chem., 13, 13-37 (2014)

23) Kim D-Y, Kim M-S, Sa B-K, Kim M-B, Hwang J-K. Boesenbergia pandurata attenuates diet-induced obesity by activating AMP-activated protein kinase and regulating lipid metabolism. Int. J. Mol. Sci., 13, 994-1005 (2012).

24) Tuchinda P, Reutrakul V, Claeson P, Pongprayoon U, Sematong T, Santisuk T, Taylor WC. Anti-inflammatory cyclohexenyl chalcone derivatives in Boesenbergia pandurata. Phytochemistry, 59, 169-173 (2002).

25) Wongwan T, Kittayaruksakul S, Asavapanumas N, Chatsudthipong V, Soodvilai S. Activation of liver X receptor inhibits OCT2mediated organic cation transport in renal proximal tubular cells. Pflugers Arch., 469, 1471-1481 (2017).

26) Thongnuanjan P, Soodvilai S, Chatsudthipong V, Soodvilai S. Fenofibrate reduces cisplatin-induced apoptosis of renal proximal tubular cells via inhibition of JNK and p38 pathways. J. Toxicol. Sci., 41, 339-349 (2016)

27) Baliga R, Ueda N, Walker PD, Shah SV. Oxidant mechanisms in toxic acute renal failure. Drug Metab. Rev., 31, 971-997 (1999).

28) Ciarimboli G, Deuster D, Knief A, Sperling M, Holtkamp M, Edemir B, Pavenstädt H, Lanvers-Kaminsky C, am Zehnhoff-Dinnesen A, Schinkel AH, Koepsell H, Jürgens H, Schlatter E. Organic cation transporter 2 mediates cisplatin-induced oto- and nephrotoxicity and is a target for protective interventions. Am. J. Pathol., 176,
1169-1180 (2010).

29) Filipski KK, Mathijssen RH, Mikkelsen TS, Schinkel AH, Sparreboom A. Contribution of organic cation transporter 2 (OCT2) to cisplatin-induced nephrotoxicity. Clin. Pharmacol. Ther., 86, 396-402 (2009).

30) Kim D, Lee MS, Jo K, Lee KE, Hwang JK. Therapeutic potential of panduratin A, LKB1-dependent AMP-activated protein kinase stimulator, with activation of PPAR $\alpha / \delta$ for the treatment of obesity. Diabetes Obes. Metab., 13, 584-593 (2011).

31) Kim MS, Pyun HB, Hwang JK. Panduratin A, an activator of PPAR- $\alpha / \delta$, suppresses the development of oxazolone-induced atopic dermatitis-like symptoms in hairless mice. Life Sci., 100, 45-54 (2014).

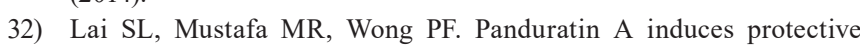
autophagy in melanoma via the AMPK and mTOR pathway. Phytomedicine, 42, 144-151 (2018).

33) Mishra J, Mori K, Ma Q, Kelly C, Barasch J, Devarajan P. Neutrophil gelatinase-associated lipocalin: a novel early urinary biomarker for cisplatin nephrotoxicity. Am. J. Nephrol., 24, 307-315 (2004).

34) Kim H, Kim MB, Kim C, Hwang JK. Inhibitory effects of panduratin A on periodontitis-induced inflammation and osteoclastogenesis through inhibition of MAPK pathways in vitro. J. Microbiol. Biotechnol., 28, 190-198 (2018).

35) Yun J-M, Kwon H, Hwang J-K. In vitro anti-inflammatory activity of panduratin A isolated from kaempferia pandurata in RAW264.7 cells. Planta Med., 69, 1102-1108 (2003).

36) Aschauer L, Carta G, Vogelsang N, Schlatter E, Jennings P. Expression of xenobiotic transporters in the human renal proximal tubule cell line RPTEC/TERT1. Toxicol. In Vitro, 30 (1 Pt. A), 95-105 (2015).

37) $\overline{\mathrm{Ma} F Y}$, Liu J, Nikolic-Paterson DJ. The role of stress-activated protein kinase signaling in renal pathophysiology. Braz. J. Med. Biol. Res., 42, 29-37 (2009).

38) Nowak G. Protein kinase C- $\alpha$ and ERK1/2 mediate mitochondrial dysfunction, decreases in active $\mathrm{Na}$ transport, and cisplatin-induced apoptosis in renal cells. J. Biol. Chem., 277, 43377-43388 (2002).

39) Oh GS, Kim HJ, Choi JH, Shen A, Choe SK, Karna A, Lee SH, Jo HJ, Yang SH, Kwak TH, Lee CH, Park R, So HS. Pharmacological activation of NQO1 increases $\mathrm{NAD}^{+}$levels and attenuates cisplatinmediated acute kidney injury in mice. Kidney Int., 85, 547-560 (2014).

40) Sohn JH, Han K-L, Lee S-H, Hwang J-K. Protective effects of panduratin A against oxidative damage of tert-butylhydroperoxide in human HepG2 cells. Biol. Pharm. Bull., 28, 1083-1086 (2005).

41) Harrach S, Ciarimboli G. Role of transporters in the distribution of platinum-based drugs. Front. Pharmacol., 6, 85 (2015).

42) Katsuda H, Yamashita M, Katsura H, Yu J, Waki Y, Nagata N, Sai Y, Miyamoto K. Protecting cisplatin-induced nephrotoxicity with cimetidine does not affect antitumor activity. Biol. Pharm. Bull., 33, 1867-1871 (2010). 